\title{
TREATING GUNS LIKE CONSUMER PRODUCTS
}

\author{
DAVID B. KOPEL ${ }^{\dagger}$
}

"Guns are the most lethal, least regulated product in the U.S.," says the gun control lobby Handgun Control, Inc. '. Advocates of more restrictive firearms laws, including gun bans, have taken up the mantra of treating "guns like other consumer products." The fathers of this idea, and its most articulate champions, are Stephen Teret and Jon Vernick, and I am honored to have the opportunity to contribute to the dialogue about this new concept.

Teret and Vernick are among the smartest and most fair-minded people working on the gun issue; they consistently frame their arguments to appeal to reason rather than to negative emotions. Were all of the Great American Gun Debate conducted in Teret and Vernick's style, our political life would be more civil.

I will essay a closer look at the implications of treating guns like consumer products. First, I compare the regulatory treatment of guns to that of two other consumer products associated with a large number of deaths: automobiles and alcohol. I suggest that, statistically speaking, automobiles and alcohol are at least as dangerous as guns. Yet were we to treat guns like automobiles or alcohol, we would have to remove most gun restrictions because guns are already regulated much more strictly than automobiles or alcohol.

† Research Director, Independence Institute, www.i2i.org; Associate Policy Analyst, Cato Institute, www.cato.org; Adjunct Professor, NYU School of Law 1998-1999; coauthor of GUN CONTROL \& GUN RIGHTS (NYU Press, forthcoming 2001).

1 Handgun Control, Inc., After Cars, Liquor, and Cigareltes . . . Is the Gun Industry Next? (visited March 7, 2000) <http://www.handguncontrol.org/press/archive/ symposium.htm>.

${ }_{2}^{2}$ Maya Sinha, Biting Bullets, MOJOwne (visited Feb. 8, 2000) <http://www.mojones.com/mother_jones/JF95/bullets.html>; see also Jolns Hopkins Center for Gun Policy and Research (visited Feb. 8, 2000) <http://infosys.jhsph.edu /centers/gunpolicy/> ("[G]uns can be regulated ... as we regulate the safety of other consumer products."); Violence Policy Center, Landmark Legislation To Set Safety Siandards for American-Made Handguns Introduced by Senator Barbara Boxer (visited Feb. 8, 2000) <http://www.vpc.org/press/9701boxr.htm> ("[F]irearms should be held to the same safety standards as all other consumer products . . . ."). See generally Katherine Kaufer Christoffel, Toward Reducing Pedialric Injuries from Firearms: Charting a Legislative and Regulatory Course, 88 PEDIATRICs 294 (1991); David Hemenway \& Douglas Weil, Phasers on Stun: The Case for Less Lethal Weapons, 9 J. POL'Y ANALYSIS \& MGMr. 94 (1990). 
Next, I examine several particular proposals for "treating guns like consumer products" which have been advanced by Teret and Vernick and by other proponents of the slogan, such as Handgun Control, Inc., and the Violence Policy Center. These proposals include censoring gun advertising, imposing certain design modifications on firearms (including "smart gun" mandates), and banning handguns-actions to be accomplished by administrative decree rather than by legislative choice. I suggest that the censorship proposals aim simply to silence one side of a controversial policy debate; that the proposed design modifications would increase firearms accidents and impair life-saving defensive firearms uses; and that banning handguns is too momentous a decision to be undertaken by unelected administrators.

Finally, I argue that firearms should be treated like other consumer products, such as newspapers and books, which are all protected by the Bill of Rights and by state constitutions.

\section{TREATING GuNS LIKE CARS}

The United States has both more guns and more cars per capita than any other nation. ${ }^{3}$ Both products are seen by some as quintessential tools of American individualism. Advocates of a more European-style social order, in which people rely more on the government for mobility and security, decry the widespread use of these products. Yet, while a minority of Americans might prefer that these products had never been invented, the majority appear content to live in a world with cars and guns-and also content to have reasonable regulations placed on these potentially dangerous products. This Part explains the true consequence of regulating guns in the same fashion as cars, and then examines the relative dangers of these two consumer products.

\section{A. Car Laws vs. Gun Laws}

Should we start treating guns like cars? Handgun Control, Inc. has been saying so for years, and Vice President Gore agreed in the summer of 1999. As he stated,

3 See JAN J.M. VAN DIJK ET AL., EXPERIENCES OF CRIME ACROSS THE WORID: KeY FINDINGS OF THE 1989 INTERNATIONAL CRIME SURVEY 47, 97 (1990) (noting that "the mean number of cars per household in the USA was 2.2 as against 1.2 for all countries" and that " $[t]$ he ownership of handguns was much more common in the USA . . . than elsewhere"); BUREAU OF TRANSP. STAT. ANN. REP. 1996, at 219 (citing statistics showing that in 1992, the United States had more cars per capita than any other nation). 
As President ... I will fight for a national requirement that every state issue photo licenses [for handgun buyers].... We require a license to drive a car in this nation, to keep unsafe drivers off the road. ... Now we should require a license to own a handgun-so people who shouldn't have them can't get them.

Gore further suggested that prospective licensees should have to "pass a background test, and pass a gun safety test," a plan that would cause the gun lobby to "have a fit."

If one extended Gore's analogy between gun licenses and drivers' licenses to the proposal that guns should be generally treated like cars, it could lead to the most massive decontrol of firearms in American history. Vice President Gore's proposal seeks a high degree of administrative regulation of guns-but a closer examination of current regulations reveals that guns are already far more regulated than cars. Laws that would really treat guns more like cars would be much less restrictive than most current gun laws, and I would welcome such a result. Let us truly treat guns like cars and sweep away most existing regulations.

The first law to go would be the 1986 federal ban on manufacture of new machine guns for sale to ordinary citizens. ${ }^{6}$ Machine guns were banned because they fire much more rapidly than ordinary guns, and this high-speed potential was considered dangerous and unnecessary-since no ordinary person had a need for such a high-speed gun. We do not ban cars like Porsches just because they are high-powered and can be driven much faster than the speed limit. Even though it is much easier to exceed the speed limit in a Porsche than in a Hyundai, we let people choose their cars regardless of their potential for speeding abuse. We even allow people to buy 13,000 horsepower Pratt \& Whitney Jet Cars, which seem almost deliberately designed for speeding.

Likewise, we do not ban automobiles because they are underpowered, or are made with poor quality metal. Those who want a Yugo can buy one. Under this analogy, the state-level bans on inexpensive

4 Gore 2000, Remarks as Prepared for Delivery by Vice President Al Gore Fighting Crime for America's Families (July 12, 1999) (visited Feb. 7, 2000) <http://www.algore2000.com/ speeches/speeches_crime_071299.html $>$.

5 Id. Were the gun lobby to consider its bottom line, the fit would be one of ecstasy. The Gore proposal would be a full-employment guarantee for all 40,000 NRAcertified firearms safety instructors. Because most of the instructors currently teach firearms safety as a sideline, the Gore plan would probably allow them to quit their day jobs.

See 18 U.S.C. $\$ 922(0)$ (1994). 
guns" (so-called "junk guns" or "Saturday Night Specials") and federal rules against the import of cheap guns would have to go. These laws are based on the theory that consumers should not be allowed to purchase guns made from metal that melts at too low of a temperature, because such guns are not well-made enough.

Further, if we agree with Handgun Control, Inc. President Robert Walker that we need to "treat[] guns like cars," we must repeal the thousands of laws regulating the purchase of firearms and their possession on private property. The simple purchase of an automobile is subject to essentially no restrictions. When a buyer shows up at the dealer's showroom, the dealer does not conduct a background check to find out if the buyer has a conviction for vehicular homicide or drunk driving. The only "waiting period" for car purchases runs from the time of the buyer's decision to purchase to the time the salesman hands him the keys. This waiting period may last a half hour or more if the auto dealership has a great deal of paperwork, or it may be even shorter.

In contrast, several states impose a waiting period on firearms purchases of several days to several weeks. ${ }^{9}$ Furthermore, firearms are the only product in the United States for which FBI permission, via the national background check, is required for every single retail consumer purchase. ${ }^{10}$ Every time a person attempts to buy a gun, the gun

7 See, e.g., MiNN. STAT. ANN. $\$ 624.716$ (West 1987) (prohibiting the sale or manufacture of "Saturday Night Specials").

${ }^{8}$ Hardball with Chris Mathews: Bob Walker, President of Handgun Control, Discusses Gun Control in the Wake of the LA Shootings (CNBC television broadcast, Aug. 11, 1999), available in. LEXIS, Nexis Library, News Group File; see also Katina Johnstone, Letter to the Editor, Treat Guns Like Cars, N.Y. TIMES, June 1, 1999, at A22 (arguing that regulating guns like cars would help keep guns away from teenagers and criminals); Teens in Civic Forum Differ over Issue of Youth Violence and Control of Guns, CHATTANOOGA TIMES \& FREE PRESS, May 12, 1999, at A11 (quoting Robert Walker, the president of Handgun Control Inc., as telling Florida high school students that "We need to treat gun like cars.").

S See, e.g., CAL. PENAL CODE $\$ 12072$ (c) (1) (West 1992 \& Supp. 1999) (requiring a ten-day waiting period); CONN. GEN. STAT. ANN. $\$ 29-33$ (b) (West Supp. 1999) (twoweek waiting period); DEL. CODE ANN. tit. 11, $\$ 1448$ A(c) (2) (1995) (three-day waiting period); FLA. STAT. ANN. $\$ 790.0655$ (1)(A) (West 1992 \& Supp. 2000) (three-day waiting period); IND. CODE ANN. \$ 35-47-2-8(c) (West 1998) (seven-day waiting period); MD. ANN. CODE of $1957 \S 442$ (c) (seven-day waiting period); MINN. STAT. ANN. $\S$ 624.7132(4) (seven-day waiting period) (West 1987 \& Supp. 2000); N.J. STAT. ANN. § 2C:58-2(a) (5) (West 1995) (seven-day waiting period); R.I. GEN. LAWS § 11-47-35 (a) (1) (West 1994 \& Supp. 1998) (seven-day waiting period).

${ }^{10}$ See 18 U.S.C. \$ 922(t) (1994) (requiring dealers to contact the national instant criminal background check system for each transfer of a firearm to a non-dealer). The FBI's "instant check" of the gun buyer may take up to three business days. See 18 
store's owner must call the FBI for permission to complete the sale. If the FBI gives permission for a gun sale on Monday and the buyer returns on Tuesday to purchase a second gun, the store must call the FBI again.

Virtually no restrictions are imposed on car owners who operate their automobiles on private property. A ranch owner whose driver's license is revoked can still drive his jeep all over the ranch without penalty. Indeed, he can drink a case of beer before driving around his ranch and still enjoy the ride knowing that he is not violating a single law, ${ }^{\text {"1 }}$ provided that he does not injure an innocent person.

If we followed the analogy about treating guns like cars, we could abolish all laws concerning gun storage in the home, as well those banning gun possession by certain persons on private property. Current federal law outlaws gun possession, even on private property, by those previously convicted of a violent or nonviolent felony ${ }^{12}$ or a misdemeanor involving domestic violence, ${ }^{13}$ (such as two brothers having a fistfight on their front lawn thirty years ago), those dishonorably discharged from the military, ${ }^{14}$ drug users (defined by regulation as any use in the last year), ${ }^{15}$ illegal aliens, ${ }^{16}$ and various other "prohibited persons." sion (or all handgun possession) on special state-issued licenses. ${ }^{18}$ If we really treated guns like cars, all of these laws would be swept away.

Most cities do prohibit property owners from storing their cars in an unsightly manner (for example, on cinder blocks in the front

U.S.C. $\S 922(t)$ (1) (B) (ii) (1994) (requiring a three-day waiting period for the national background check system to notify the dealer of a problem with the gun purchase).

"Of course, if any form of negligent or reckless conduct with one's auto on one's own property results in injury to an innocent person, or to someone else's property, the owner will be financially responsible and may be prosecuted for violating laws against reckless endangerment. See, e.g., 18 PA. CoNS. STAT. ANN. $\$ 2705$ (West 1973 \& Supp. 1999) (defining the offense of recklessly endangering another person); MODEI. PENAL Code $\$ 211.2$ (1980) (same).

${ }^{12}$ See 18 U.S.C. $\$ 922(\mathrm{~g})(1)$ (1994).

13 See 18 U.S.C. $\$ 922(\mathrm{~g})$ (9) (Supp. III 1997).

${ }^{14}$ See 18 U.S.C. $\$ 922(\mathrm{~g})(6)$ (1994).

${ }^{15}$ See 18 U.S.C. $\$ 922(g)(3)$ (1994) (prohibiting firearm possession by anyone who "is an unlawful user of or addicted to any controlled substance").

${ }^{16}$ See 18 U.S.C. $\$ 922(\mathrm{~g})(5)$ (1994).

${ }^{17}$ See 18 U.S.C. $\$ 922(\mathrm{~g})$ (1994) (prohibiting firearm possession by fugitives, mental defectives, persons who have renounced their U.S. citizenship, and persons subject to restraining orders, in addition to the classes already named).

${ }^{18}$ See, e.g., MASS. ANN. LAwS ch. 140, § 129C (Law. Co-op. 1995) (prohibiting ownership or possession of a firearm by any person unless she has been issued a firearm identification card). 
yard), or from parking too many cars on the public street in front of their house. Thus, gun owners will have to accept laws against leaving nonfunctional guns strewn about their front yard, and will not be allowed to leave excessive numbers of guns on the street (gun control groups frequently complain that there are "too many guns on the street").

If a person keeps a car on his own property, he can tow the car to a friend's property and drive it on that property. As long as he is merely towing the car, he needs no license and no restrictions apply. Thus, gun owners should be allowed to transport their unloaded guns to private property such as a shooting gallery for use on that property. Jurisdictions such as New York City would no longer have the power to require a separate "target permit" just to take a gun to the local pistol range.

Supposing that the auto owner wants to use his car on public property, as most people do, a driver is required to be duly licensed. To obtain a license to drive a car anywhere in public, most states require that the licensee be at least fifteen or sixteen years of age, take a written safety test that requires an IQ of no more than eighty to pass, drive the car for an examiner, and demonstrate to the examiner that the driver knows how to operate the car and obey basic safety rules and traffic signs. The license will be revoked or suspended if the driver violates various safety rules or causes an accident while driving in public. Except in egregious cases, first or second offenses do not usually result in license revocations. Once the license is issued, it is good in every state.

Vice-President Gore appeared to focus on these driver's license requirements when discussing the need for handgun licensing, although he failed to recognize that such requirements only apply to cars used in public and not to those operated on private property. The licensing of guns touted by Gore is already in effect in thirty states, where adults with a clean record can obtain a permit to carry a concealed handgun for lawful protection. ${ }^{20}$ To make the concealed handgun licensing system exactly like the driver's system would re-

${ }^{19}$ The license is issued pursuant to New York Penal Law, see N.Y. PENAL LAW § $400.00(2)$ ( $f$ ) (McKinney 1999). For the existence of licenses under this section described as "target permits," see, for example, People v. Ocasio, 441 N.Y.S. 2d 148 (N.Y. Sup. Ct. 1981).

${ }^{20}$ Note that Vermont requires no permit, so that there are 31 states in which gun carrying is lawful for law-abiding adults. See JOHN R. LOTTJR., MORE GUNS, LESS CRIME 46 (1998) (demonstrating the variances among states on handgun rules). 
quire a few tweaks, such as reducing the minimum age for a gun license (currently twenty-one or twenty-five in most states) as well as the licensing fees, which can run over $\$ 100$ in many states; mandating a written exam in those few states without one; adding a practical demonstration test (currently administered in Texas but not in most other states); and making licenses valid in all states rather than in only the issuing state. Statewide validity of gun licenses could spur the proliferation of rent-a-gun stores for travelers, similar to the current rent-acar system. ${ }^{21}$ In addition, the nineteen states that currently do not give handgun-carrying permits to every person with a clean record would have to change their laws.

Some jurisdictions require the carry licensee only to register either the type of handgun for which she was trained by a handgun instructor or the particular handguns she will carry. ${ }^{22}$ The Elbert County, Colorado, sheriff does this, as do some sheriffs in other states. Under the treat-guns-like-cars rule, an owner would have to register every gun that would be carried in public and pay an annual or semiannual registration tax. Such registration would also be required for hunting or target shooting guns used on public lands. The theory of auto registration is that once the auto is driven on public streets, it acquires a certain public character and must be registered, unlike an auto that is only used on private property. The strict "treat guns like cars" analogy from Handgun Control, Inc., would therefore support registration of guns that are carried or used in public places. Of course, once a person gets a driver's license, she can drive in any area open to the public. Thus, we would have to repeal all the laws against carrying guns within a thousand feet of a school, in bars, or on government property. ${ }^{23}$

Although legislative bodies do regulate gun design through laws about machine guns, "assault weapons," and inexpensive guns, no federal agency has the authority to impose new design standards on firearms. By contrast, federal regulators do impose a wide variety of safety rules on automobiles. Thus, the one significant way in which treating guns like cars would lead to more restrictive gun laws would be by allowing federal regulators to impose design controls on fire-

${ }^{21}$ Allowing licensed gun owners to carry guns while traveling might substantially reduce crimes against tourists in rental cars in places such as Atlanta and Miami.

${ }^{22}$ See, e.g., TEX. GOV'T CODE ANN. $\$ 411.177$ (West 1998).

${ }^{23}$ See, e.g., 18 U.S.C. \$ 922(q) (Supp. III 1997) (prohibiting possession of a firearm in a school zone); 18 U.S.C. $\$ 930$ (1994) (prohibiting possession of firearms in federal facilities). 
arms. This point, made by Teret and Vernick, will be addressed in detail in Part IV. For now, it is sufficient to recognize that if we use the "treat guns like consumer products" approach to create the regulatory regime advocated by Teret and Vernick, then we would have to jettison most current gun laws that treat guns far more severely than cars or other consumer products. Almost all such additional products are less regulated than cars and require no license and registration at all, even for public use.

\section{B. The Comparative Dangers of Guns and Cars}

When faced with the prospect of treating guns like cars, some gun control advocates argue that there are important differences in dangerousness between guns and cars. This is true: cars are much more dangerous.

The annual death toll from automobiles is roughly 8000 higher than that from firearms. ${ }^{24}$ In 1994, there were roughly thirty-two automobile deaths for every 100,000 automobiles in the United States. ${ }^{25}$ The same year, there were roughly fifteen firearm deaths for every 100,000 firearms in the United States. ${ }^{26}$ In any given year between 1990 and 1994, the average car was about twice as likely to cause a death as was the average gun.

Table 1. Automobiles

\begin{tabular}{|c|c|c|c|}
\hline Year & Auto Fatalities $^{27}$ & $\begin{array}{c}\text { Number of } \\
\text { Autos }^{28}\end{array}$ & $\begin{array}{l}\text { Fatality Rate per } \\
\text { 100,000 Autos }\end{array}$ \\
\hline 1990 & 46,814 & $143,549,627$ & 32.6 \\
\hline 1991 & 43,536 & $142,955,623$ & 30.5 \\
\hline 1992 & 40,982 & $144,213,429$ & 28.4 \\
\hline 1993 & 41,893 & $146,314,296$ & 28.6 \\
\hline 1994 & 42,524 & $133,929,662$ & 31.8 \\
\hline Average & 43,150 & $142,192,527$ & 30.3 \\
\hline
\end{tabular}

${ }^{24}$ See infra text accompanying notes $25-32$ (reporting the average number of fatalities from automobiles and firearms for the period 1990-1994).

${ }^{25}$ See infra tbl.1.

${ }^{26}$ See infra tbl.2.

${ }^{27}$ See THE WORID ALMANAC AND BOOK OF FACTS 2000, at 895 (Robert Famighetti et al. eds., 2000). The above data do not include suicide by poisoning from automobile exhaust. I would like to thank the Independence Institute's Robert Racansky for gathering the car/gun data.

${ }^{23}$ See id. at 707 ("Cars Registered in the U.S., 1900-96"). 
Table 2. Firearms

\begin{tabular}{|l|l|l|l|l|l|l|}
\hline Year & $\begin{array}{l}\text { Firearms } \\
\text { Accidental } \\
\text { Deaths }^{29}\end{array}$ & $\begin{array}{l}\text { Firearms } \\
\text { Suicide } \\
\text { Deaths }\end{array}$ & $\begin{array}{l}\text { Firearms } \\
\text { Homicide } \\
\text { Deaths }^{\text {s1 }}\end{array}$ & $\begin{array}{l}\text { Total } \\
\text { Firearms } \\
\text { Deaths }^{32}\end{array}$ & $\begin{array}{l}\text { Number of } \\
\text { Firearms }\end{array}$ & $\begin{array}{l}\text { Rate of death } \\
\text { per 100,000 } \\
\text { firearms }\end{array}$ \\
\hline 1990 & 1,416 & 18,885 & 13,035 & 33,336 & $212,823,547$ & 15.7 \\
\hline 1991 & 1,441 & 18,526 & 14,373 & 34,340 & $216,695,946$ & 15.8 \\
\hline 1992 & 1,409 & 18,169 & 15,489 & 35,067 & $222,067,343$ & 15.8 \\
\hline 1993 & 1,521 & 18,940 & 16,136 & 36,597 & $228,660,966$ & 16.0 \\
\hline 1994 & 1,356 & 18,765 & 15,456 & 35,577 & $235,604,001$ & 15.1 \\
\hline Avg. & 1,429 & 18,657 & 14,898 & 34,983 & $223,170,361$ & 15.7 \\
\hline
\end{tabular}

One response to data such as this is that guns are designed to kill. Yet killing is legal: animals may be killed in compliance with hunting laws just as humans may be killed under laws authorizing the use of deadly force against violent felony attacks. Some people might dispute the moral legitimacy of either hunting or the defensive use of force, an issue which might be relevant to a person ranking the comparative morality of manufacturers of various products. ${ }^{34}$ To the parents of a dead child, however, the fact that the car that killed their child was not "designed" to kill is meaningless. If someone is dead, relatives are no better off because the instrument of death had a particular design purpose.

Another important difference between cars and firearms is that one family's ownership of a car usually confers little benefit on other families, whereas gun ownership benefits society as a whole, not just

${ }^{29}$ See THE WORLD ALMANAC AND BOOK OF FACTS 1998, at 965 (Robert Famighetti et al., eds., 1996).

${ }^{30}$ See THE WORLD ALMANAC AND BOOK OF FACTS 1996, at 967 (Robert Famighetti et al., eds., 1996).

${ }^{31}$ See Federal BUREAU OF INVESTIGATION, UNIFORM CRIME REPORTS FOR THE UNITED STATES 18 tbl.2.10 (1994).

${ }^{32}$ See THE WORLD ALMANAC AND BOOK OF FACTS 1998, supra note 29, at 968; THE WORLD ALMANAC AND BOOK OF FACTS 1996, supra note 30, at 967; THE WORLD ALMANAC AND BOOK OF FACTS 1997, at 968 (Robert Famighetti et al. eds., 1997); THE WORLD ALMANAC AND BOOK OF FACTS 1995, at 965 (Robert Famighetti et al. eds., 1995); THE WORLD ALMANAC AND BOOK OF FACTS 1994, at 963 (Robert Famighetti et al., eds., 1994).

ss See GARY KIECK, TARGEIING Guns: FIREARMS AND THEIR CONIROL 96-97 tbl.3.1 (1997).

${ }^{34}$ Many guns are designed for shooting paper targets rather than for killing animals. Guns designed for self-defense purposes are designed to save innocent lives. 
the owner. If my neighbors buy an additional car, my family is no better off; indeed, we may be slightly worse off, since there is more competition for on-street parking and more crowding on the highway. While cars are usually only beneficial to their owners, firearms protect both owners and non-owners alike. As John Lott's research details, laws which allow law-abiding citizens to carry concealed handguns for protection lead to between a five and eight percent drop in violent crime. ${ }^{35}$ Because criminals do not know which potential victims may be carrying a concealed handgun, everyone (not just gun carriers) benefits from the general deterrent effect.

Similarly, the United States has a much lower "home invasion" burglary rate than do nations such as Canada, Great Britain, and Australia, which outlaw defensive gun ownership. American burglars-in sharp contrast to their Commonwealth counterparts-work hard to avoid entering occupied homes. Because about half of American homes have guns and can lawfully have firearms ready to use for protection against burglars, American burglars usually avoid home invasions in order to avoid getting shot. Because burglars do not know which homes have guns and which do not, they must take care to enter when no one is home. Thus, because some homes have firearms, all American families are more secure from home invasion. ${ }^{36}$

Moreover, the design argument underscores how dangerous automobiles really are. Almost all firearm deaths come from intentional shootings-homicides or suicides. Only four percent of firearm deaths are accidental. ${ }^{37}$ Cars are thus twice as likely to kill as guns are, even though the killer behind the wheel does not intend to take a life. Significantly, about half of the people who die from guns are suicide victims who chose to die, whereas few people who die in automobile accidents chose to die. ${ }^{38}$

${ }^{35}$ See LOTT, supra note 20, at 51.

${ }^{36}$ See GARY KIECK, POINT BLANK: GUNS AND VIOLENCE IN AMERICA 138-4I (1991) (noting, albeit tentatively, that civilian ownership of guns by Americans has a deterrent effect on violent crime and injuries linked to burglaries).

${ }^{37}$ See supra tbl.2 (showing that from 1990-1994, of the average of 34,984 firearm deaths per year, 1,429 were accidental).

${ }^{3 s}$ See supra tbl.2 (showing that, from 1990-1994, suicide deaths comprised $53 \%$ of total firearm deaths). Moreover, being the victim of an automobile accident is more common than being victimized by a gun. According to a poll conducted for Teret and Vernick's research center, $20 \%$ of the American population has been threatened by a gun. See NATIONAL OPINION RESEARCH CTR., THE JOHNS HOPKINS CTR. FOR GUN POLICY \& RESEARCH, 1996 NATIONAL GUN POLICY SURVEY 42 (1997). Is there a driver in the United States who has had a license for more than a few months who has not been deliberately intimidated by another driver using the automobile as a weapon? It 
Firearm policy has been significantly affected by several highlypublicized cases of mass murder. For example, in April 1999, two young men, armed with two guns each, killed thirteen people at Columbine High School in Littleton, Colorado. The worst firearms mass murder in the United States was perpetrated by a man who murdered two dozen people at a Luby's Cafeteria in Killeen, Texas. Contrast the Luby's murderer, who intended to kill, with Larry Mahoney-a drunk driver who did not intend to hurt anyone but caused an accident that killed twenty-seven people in May 1988. What is our public policy response to mass killers like Larry Mahoney? Notably, efforts to control drunk drivers involve virtually no restrictions on people who do not drive drunk, other than roadside sobriety checkpoints to check for drunk drivers. With automobiles, our laws target people who intentionally or recklessly misuse the product; we do not blame lawful users for criminal misuses. But after Columbine, the "gun culture" and the NRA were blamed for the acts of two murderers.

It should be noted that the type of people who cause accidents with automobiles are the same type who cause accidents with firearms. Many gun and automobile accidents involving adults are the result of recklessness more than ignorance. Adults and older teenagers who cause firearms accidents are unlike the rest of the population. They are "disproportionately involved in other accidents, violent crime and heavy drinking." $"$ Indeed, they tend to have a record of reckless driving and automobile accidents. ${ }^{40}$ Long before Stephen Teret, Jon Vernick, and I were old enough to write anything on firearms policy, psychologist Albert Elkin observed:

There is no doubt that a large number of automobile deaths are caused by unstable people who are highly neurotic or psychotic or psychopathic.

is not uncommon for drivers to tailgate other cars so as to cause a serious risk of a major accident, or to force other drivers to slam on the brakes to avoid collision with an auto intentionally cutting in front of another car. The number of deaths from these intentional misuses of cars to threaten people with death by collision is hardly insignificant.

${ }^{39}$ Philip J. Cook, The Role of Firearms in Violent Crime: An Interpretative Review of the Literalure, in CRIMINAL VIOLENCE 236, 269 (Marvin E. Wolfgang \& Neil Alan Weiner eds., 1982); see also KIECK, supra note 36, at 282-87 (citing studies that show that accidental shooters were more likely to have been arrested for violent acts, in connection with alcohol, or involved in highway crashes); Roger Lane, On the Social Meaning of Homicide Trends in America, in I VIOLENCE IN AMERICA 55, 59 (Ted Robert Gurr ed., 1989) (asserting that "the psychological profile of the accident-prone suggests the same kind of aggressiveness shown by most murderers").

${ }^{10}$ See KIECK, supra note 36, at 286 (discussing a study by Julian A. Waller and Elbert B. Whorton finding that accidental shooters were likely to have been involved in traffic accidents). 
An attack on the problems that pertain to the misuse of firearms is an attack on the same ones that pertain to the misuse of automobiles.

\section{GUNS AND ALCOHOL}

By some estimates, alcohol is responsible for 100,000 deaths each year $^{42}$-greater than firearms and automobiles combined. ${ }^{43}$ In 1996 , for example, $41 \%$ of all traffic fatalities were alcohol-related. ${ }^{44}$ Fortyone percent of convicted jail inmates committed their most recent offense while using alcohol. ${ }^{45}$ Of convicted violent offenders in state prison, $38 \%$ were drinking at the time of their crime. ${ }^{46}$ Convicted murderers in state prison reported that alcohol was a factor in approximately $50 \%$ of the murders they committed. ${ }^{47}$ Twenty-eight percent of convicted robbers in state prison were likewise under the influence of alcohol at the time of their offense. ${ }^{48}$ About one third of child molesters were drinking before committing the offense for which they were convicted. ${ }^{49}$ As with firearms, the presence of alcohol

41 Gun and Car Fatalities-Related Problems?, AM. RIFLEMAN, Dec. 1966, at 40; see also infra Part IV (discussing further the limited ability of laws or product designs to protect those who engage in reckless behavior).

${ }^{42}$ See J. Michael McGinnis \& William H. Foege, Actual Causes of Death in the United States, 270 JAMA 2207, 2208 (1993) (identifying the major contributors to mortality and the total number of deaths caused by each).

${ }^{43}$ Of course, some alcohol deaths involve automobiles (drunk driving) and firearms (accidents and suicide/homicide perpetrators who were disinhibited by alcohol). One source attributes nearly 20,000 automobile deaths per year to alcohol. See Terry S. Zobeck et al., Years of Potential Life Lost and Other Trends in Alcohol-Related Fatal Traffic Crashes: 1977-1987, 14 ALCOHOL HEALTH \& RES. WORLD 63, 63 (1990).

14 See LAWRENCE A. GREENFELD, ALCOHOL AND CRIME: AN ANALYSIS OF NATIONAL DATA ON THE PREVALENCE OF ALCOHOL INVOLVEMENT IN GRIME vi (1998) (prepared for the Assistant Attorney General's National Symposium on Alcohol Abuse and Crime, Apr. $5-7,1998$ ) (noting statistics for drunk driving-related arrests and fatal accidents in 1996).

45 See Caroline Wolf Harlow, Profile of Jail Inmates 1996, in 1998 BUREAU OF JUSTICE STATISTICS: SPECIAI REPORT, DEP'T OF JUST. REP., at 9, tbl.13 (noting the percentage of jail inmates who committed their current offense while under the influence of drugs or alcohol).

46 See GREENEELD, supra note 44 , at vii.

${ }^{47}$ See id. at 30 fig. 37 (showing the percent of convicted murderers who used alcohol by the murderer's relationship to his victim). See generally ROBERI NASH PARKER, ALCOHOL \& HOMICIDE (1995) (exploring the relationship between alcohol and homicide in American society).

${ }^{43}$ See id. at 25 fig.32 (diagramming the percentage of inmates drinking at the time of their offense).

${ }^{19}$ See Judy Roizen, Estimaling Alcohol Involvement in Serious Events, in NATIONAL INST. ON ALCOHOL ABUSE AND ALCOHOLISM, ALCOHOL CONSUMPTION AND RELATED PROBLEMS 179, 210 (1982). 
tends to make injuries from violent incidents more severe. ${ }^{50}$

In addition, as many as eighty percent of persons who attempted to commit suicide were drinking beforehand. ${ }^{51}$ Although most drinkers drink responsibly, it would be absurd to deny that irresponsible drinking helps cause an immense number of deaths and crime. For a while, the United States attempted to address the problem of alcohol abuse by banning alcohol altogether. When Prohibition caused more problems than it fixed, more moderate regulations replaced the absolute ban on alcohol. These regulations could be considerably tougher than they are. ${ }^{52}$

${ }^{50}$ See KaI PERnanen, AlCOHol in Human Violence 130, 133 (1991) (discussing theories regarding the determinant role of alcohol in human aggression).

${ }^{51}$ See U.S. DEP'T OF HEALTH \& HUM. SERVS., FIFTH SPECIAI REPORT TO THE U.S. CONGRESS ON AICOHOL AND HEALTH XX ("AA]s high as four out of five of those who attempt suicide had been drinking at the time.").

${ }^{52}$ Consider the following hypothetical proposals offered by historian Clayton Cramer:

1. Every alcoholic beverage container will have a serial number, so that those who illegally sell alcohol can be identified and prosecuted.

2. All sales of alcohol will require the buyer to provide his name, address, physical description, and driver's license number on a Dealer Record of Sale form. False IDs have long been used by minors to buy alcohol, so this information will be verified before the sale is completed.

3. To discourage people who, in a moment of depression, buy a bottle, and commit suicide under the influence of alcohol, there will be a fifteen-day "cooling-off" period, during which the buyer's ID will be verified, as discussed in proposal 2.

4. Many adults have been approached by a minor outside a liquor store, asking them to buy alcohol. By requiring full identification and the serial number of the container to be purchased at the beginning of the waiting period, the legitimate buyer will not be able to add a six-pack to his order on the spur of the moment.

5. Unregistered private party transactions will be prohibited. Adults may transfer an alcoholic beverage to another adult through a licensed alcohol dealer after the fifteen-day waiting period and background check.

6. Possession of an alcoholic beverage in a public place, except while in transit to or from a licensed alcohol dealer with the package securely wrapped, will be illegal, since at any time, the temptation to whip out a six-pack, get drunk, and ram a school bus full of kids, seems to be more than many Americans can control.

7. To show that we consider alcohol-related crime to be serious, unregistered sales of alcohol will be a misdemeanor; possession of alcohol in a public place, except while in transit, will be a misdemeanor or felony, depending on prior convictions.

8. Alcoholic beverages so high in alcohol content as to have no legitimate dietary purpose, such as whiskey, gin, or rum, will require a permit from the state Attorney General, which will only be issued for "non- 
In sum, the legal system does not currently treat guns like other consumer products. They are subject to a vast range of more restrictive laws that, on the whole, are much more severe than the laws regulating consumer products that kill more people than guns, such as automobiles and alcohol.

\section{ADVERTISING}

In one important respect, firearms, like most other consumer products, are subject to significantly less regulation than alcohol, the advertising of which is rigorously censored by the Bureau of Alcohol, Tobacco and Firearms ("BATF"). ${ }^{53}$

personal, commercial" uses such as television and film production. There is no legitimate purpose to such drinks; they exist for the sole purpose of getting drunk.

9. Unlicensed possession or sale of these beverages will be a felony with up to one year in jail for unlicensed possession in a public place, or second offense possession in your home, and a minimum of four years in prison for unlicensed sale.

10. Existing owners of these "assault beverages" will be allowed to keep them, provided they are registered with the state, but no new ones will be allowed to be sold.

11. Police departments, state departments of justice, and other public agencies will be completely exempt from these restrictions, since politicians and police officers do not abuse alcohol, except in the public interest.

E-mail from Clayton E. Cramer to Firearms Regulation discussion Group (Aug. 18, 1999) (on file with the University of Pennsylvania Law Review).

Opponents of Cramer's proposals may point out that the proposals unfairly penalize and inconvenience responsible drinkers and would be ineffective in controlling alcohol abuse. Proponents could retort that these proposals are far from prohibitory (except for especially dangerous forms of alcohol) and merely impose certain inconveniences on alcohol consumers and sellers, with the intention of reducing alcohol abuse by minors and irresponsible people. If a fifteen-day waiting period on wine purchases would save one life, would it not be worthwhile?

If we simply substitute the word "firearm" for "alcohol," we find that every one of these proposals is already the law in California. See Cal. Penal Code $\$ \S 12000-12098$ (listing California's regulations governing firearms); Handgun Control, Califormia Cun Control (Press Release, Aug. 27, 1999) (discussing California's enaction of some of the strongest gun control laws in the United States, including a prohibition on the purchase of more than one handgun per month). While gun control advocates throughout the United States are pushing for similar laws, California gun control advocates consider these California laws a modest beginning and still far from what the people really need.

${ }^{53}$ See Erik Bierbauer, Note, Liquid Honesty: The First Amendment Right to Market the Health Benefits of Moderale Alcohol Consumption, 74 N.Y.U. L. REv. 1057, 1064 (1999) ("The federal government, primarily through ATF, generally has forbidden alcohol producers to refer to medical evidence of alcohol's potential benefits either on labels or in advertisements reaching beyond the point of sale."). 
As far as advertising goes, firearms are treated like every other consumer product: the Federal Trade Commission and its state analogues have the authority to prohibit unfair or deceptive advertising. On the basis of existing law, the Johns Hopkins Center for Gun Policy and Research has filed a petition with the FTC to ban firearms advertising that mentions the protective benefits of firearms. ${ }^{54}$ A separate petition on the same subject has been filed by the Center to Prevent Handgun Violence ("CPHV").

The FTC Act gives the FTC the power to ban advertising that is "deceptive" or "unfair," and the petitions allege that the defensive firearms ads are both. ${ }^{57}$ The ads are purportedly "deceptive" because gun ownership does not increase safety in the home and is in fact dangerous. Under FTC policy, an advertisement is "unfair" if it causes "substantial injury to consumers which is not reasonably avoidable by consumers themselves and not outweighed by countervailing benefits to consumers or to competition. ${ }^{58}$

The petitioners believe that the defensive gun ads are unfair because they encourage people to own guns for protection. Gun ownership leads to substantial injuries (e.g., death and nonfatal wounds), yet there are no countervailing benefits because defensive gun use is extremely rare. The petitioners support their case for the counterproductive nature of defensive gun ownership by citing several medical journal articles.

${ }^{54}$ See Jon S. Vernick et al., Regulating Firearm Advertisements that Promise Home Protection: A Public Health Intervention, 277 JAMA 1391 (1997) (summarizing the Teret and Vernick case for censorship).

${ }^{55}$ See Petilion Before the Federal Trade Commission (Feb. 14, 1996) (visited Mar. 7, 2000) <http://www.handguncontrol.org/legalaction/dockets/A3/a3ftcpethtm>. See generally Debra Dobray \& Arthur J. Waldrop, Regulating Handgun Advertising Directed at Women, 12 WHITTIER L. REV. 113 (1991) (arguing that the FTC should censor gun ads). The CPHV is the educational arm of Handgun Control, Inc. Like Teret and Vernick's Center for Gun Policy and Research, the CPHV belongs to the "HELP" network (Handgun Epidemic Lowering Plan) whose stated program is to "work toward changing society's attitude toward guns so that it becomes socially unacceptable for private citizens to have guns." Edgar A. Suter, Letter to the Editor, EMERGENCY MEDICINE NEWS, Nov. 10, 1997.

${ }^{56}$ See 15 U.S.C. $\$ 45(a)(1)$ (1994) (prohibiting "unfair or deceptive acts or practices in or affecting commerce").

${ }^{57}$ One ad shows a handgun lying on a nightstand at 11:25 p.m. next to a picture of a mother and her two children. The complaint is that the ad encourages unsafe storage of a firearm because the gun is not locked and small children live in the house. The second ad depicts a mother tucking a child into bed and recommends the Colt self-loading pistol to protect loved ones.

15 U.S.C. $\$ 45(n)$ (1994).

${ }^{59}$ One article analyzes gun deaths in homes in King County (Seattle), Washington. 
The petitioners compare the annual number of gun misuses to the annual number of defensive gun uses (which they claim to be $85,000)^{60}$ In the context of gun advertising, however, that comparison misses the point entirely. Since the number of gun misuses annually (including all gun crime) is much larger than 85,000, guns are said to have no net protective benefit. Actually, a huge fraction of gun misuse is perpetrated by persons-such as convicted felons-who are barred from purchasing guns by federal and state law. These gun misusers are not the focus of the gun industry's ads, since the gun industry targets people who can buy new guns in stores. The issue for advertising is not whether, on the whole, guns benefit society, but whether guns purchased by legal gun purchasers (adults who receive permission from the FBI) are more likely to harm than to protect purchasers' households. That illegal gun possessors cause more harm than legal gun owners prevent is irrelevant to whether a gun in the home of a law-abiding purchaser is a net danger to that home.

The "unfair" prong of the FTG's censorship authority asks whether a particular harm is "reasonably avoidable by consumers themselves." ${ }^{, 61}$ The harm of gun injury from a home handgun is entirely avoidable: following the manufacturer's instructions that accompany each firearm purchase will prevent gun accidents. Other harms are fully avoidable if the owner does not commit intentional violent felonies with the gun, does not try to kill himself, and keeps the gun away from anyone who might commit such horrible acts. Nevertheless, the Teret and Vernick petition claims that the harms of

This article did not claim to study the overall protective value of guns; the only defensive uses quantified were fatal shootings of intruders unrelated to people in the house. See Arthur L. Kellermann \& Donald T. Reay, Protection or Peril? An Analysis of FirearmsRelated Deaths in the Home, 314 NEw ENG. J. MED. 1557, 1559-60 (May-June 1986) (analyzing the circumstances of gun deaths in homes over a six-year time period).

Another article compared people who had been murdered with people who had not, and claimed to find that owning a gun elevates the risk of being murdered by 2.7 times. This study, focusing on murder victims, did not even attempt to examine any cases of successful gun use. In addition, hardly any of the murder victims were killed with their own guns; they were killed instead with guns brought into the home. The same study also found that having a security system is similarly correlated with the risk of being murdered. The obvious implication is not that owning a gun or a security system results in the murder of the owner; instead, people who are at risk of being murdered are more likely to take protective measures by buying guns and security systems. See Arthur L. Kellermann et al., Gun Ownersilip As a Risk Factor for Homicide in the Home, 329 NEW ENG. J. MED. 1084, 1084 (Sept.Oct. 1993) (claiming that there is an independent and significant increased risk of homicide if there is a gun in the home).

${ }^{60}$ See infra notes 63-64 and accompanying text (arguing that the actual number of defensive gun uses is much higher).

61 15 U.S.C. $\$ 45(n)$. 
gun ownership-especially homicides-cannot be avoided by consumers. In effect, the argument is that American consumers are by nature so hot-tempered that they cannot reasonably be expected to refrain from killing somebody. Under this view, the only way to guarantee safety is to prevent people from having any kind of gun, even a locked one. Given this dark picture of ordinary Americans as wouldbe murderers, it is not surprising that these same Americans are considered too stupid and vulnerable to be exposed to advertising about the ownership and use of handguns for protection.

The logic of the censorship petition lays the foundation for banning all gun ads, not just those touting defensive gun ownership. After all, if the risks of owning any gun at home really are so great compared to the benefits, and lawful gun owners are so incapable of controlling their behavior, then any ad that encourages people to bring a gun into the home for whatever reason could be considered "unfair.",

The censorship petitions carefully avoid extensive evidence illustrating the defensive benefits of gun ownership. Instead, they critique just one study, conducted by Professor Gary Kleck, which estimated that there were roughly 2.5 million defensive gun uses annually during the period from 1988 to $1993 .^{63}$ The petitions do not mention the dozen other studies that report the number of annual defensive gun uses as being at least in the high hundred thousands. ${ }^{64}$

More importantly, the censorship petitions ignore the most relevant evidence regarding the defensive use of guns: data from the federal government's National Crime Survey that shows that if a robbery victim does not defend herself, the robbery will succeed $88 \%$ of the time, and the victim will be injured $25 \%$ of the time. ${ }^{65}$ If the victim resists with a gun, however, the robbery "success" rate falls to $30 \%$,

${ }^{62}$ Indeed, the rationale of the censorship petitions could be extended logically to ban advertising for any other product-such as beer, cigars, or fast cars-for which a coalition of health puritans claims the harms outweigh the benefits, and which consumers are allegedly too incompetent to use responsibly.

${ }^{63}$ See Gary Kleck \& Marc Gertz, Armed Resistance to Crime: The Prevalence and Nalure of Self-Defense with a Gun, 86 J. CRMM. L. \& CRIMNOLOGY 150, 164 (1995) ("[E]ach year in the U.S. [t] here are about 2.2 to 2.5 million [defensive gun uses] of all types by civilians against humans, with about 1.5 to 1.9 million of the incidents involving use of handguns.").

${ }_{64}^{64}$ See, e.g., id. at 158 ("The Hart survey results implied a minimum of about 640,000 annual [defensive gun uses] involving handguns, while the Mauser results implied about 700,000 involving any type of gun.").

${ }^{65}$ See KLECK, supra note 36 , at 149 tbl. 4.4 . 
and the victim-injury rate falls to $17 \% .^{66}$ No other response to a robbery-from using a knife, to shouting for help, to fleeing-produces such a low rate of robbery success and victim injury. ${ }^{67}$ Of course, these statistics do not imply that drawing a gun is the safest response to every conceivable criminal attack; in some circumstances, another course, including submission, may be more prudent.

The censorship petitions were filed before publication of John Lott's research, which found that enactment of concealed handgun laws resulted in violent crime rate drops of 5-8\%. The petitioners thus cannot fairly be blamed for failing to analyze Lott's data. ${ }^{68}$ The censorship petitions, however, were filed long after data became available from several states with concealed-handgun carry laws that showed that concealed-carry permit holders virtually never misuse their guns. ${ }^{69}$ Whatever one thinks of Lott's findings about drops in the violent crime rate, the state data regarding license holders themselves clearly show that licensed gun owners are unlikely to commit gun crimes.

In addition, the analysis in the censorship petitions ignores evidence showing that the widespread presence of defensive guns in American homes plays a major role in reducing the rate of "hot" burglaries, or break-ins while the victims are home.

Looking at all available scholarly evidence, the most that one can say in favor of the anti-gun argument is that the evidence is inconclusive. The least favorable is that almost all of the antigun studies are junk science created by people with medical degrees who have little expertise in the subject at hand; ${ }^{71}$ the studies finding significant benefits from defensive gun ownership are written by some of the nation's

${ }^{66}$ See id.

${ }^{67}$ See id. at 124 (" Robbery and assault victims who used a gun to resist were less likely to be attacked or to suffer an injury than those who used any other method of self-protection or those who did not resist at all.").

${ }^{63}$ See JOHN R. LOTT, JR., MORE GUNS, LESS CRIME 51 (1997) (noting that when "state concealed-handgun laws went into effect in a county, murders fell by about 8 percent, rapes fell by 5 percent, and aggravated assaults fell by 7 percent").

${ }^{69}$ See generally Clayton E. Cramer \& David B. Kopel, "Shall Issue": The New Wave of Concealed Handgun Permil Laws, 62 TENN. L. REv. 679 (1995) (discussing concealed carry laws and conceding that their enactment presents little risk to public safety).

${ }^{70}$ See KLECK, supra note 36, at 182-84.

7 See generally Don B. Kates et al., Guns and Public Health: Epidemic of Violence or Pandemic of Propaganda?, 62 TENN. L. REV. 513 (1995) (arguing that most anti-gun literature written by medical and public health professionals is biased to validate a priori conclusions); David B. Kopel, Guns, Germs, and Science: Public Heallh Approaches to Gun Control, 84 J. MED. ASS'N OF GA. 269 (1995). 
most eminent criminologists. ${ }^{72}$

The censorship petitions endanger more than the First and Second Amendments. A Republican form of government itself is at issue. Neither Congress nor a single state legislature has ever voted to censor gun advertising. The petitioners are trying to win through bureaucracy what they could never win at the ballot box or in a legislature. When Congress created the FTC, it never contemplated that the Commission would consider censoring advertisements for mainstream concepts such as defensive gun ownership. The FTC should have promptly shipped the censorship petition back to its senders. That the FTC has spent several years apparently giving the censorship petitions serious consideration is in itself an abuse of administrative power.

The censorship petitions highlight the problem with the theory that commercial speech should receive a lesser degree of constitutional protection than noncommercial speech. The issue of defensive gun ownership is a subject of intense political debate-precisely the kind of debate which is at the heart of the First Amendment. The ads that Teret, Vernick, and the other petitioners want to censor are very much part of that debate, for the ads promote defensive gun ownership and project the idea that ordinary Americans are responsible enough to own guns for protection. The expression of this idea is entitled to First Amendment protection, regardless whether the idea is expressed in the Maryland Law Review or in a print advertisement from North American Arms.

\section{TeRET AND Vernick's GUN DESIGNS}

The FTC censorship controversy shows that power granted for one purpose-the power that Congress granted the FTC to crack down on advertising for phony patent medicines and the like-can be perverted for wholly unintended purposes. Thus, it is quite reasonable for persons who care about Second Amendment rights to be con-

72 Kleck's book Point Blank was awarded the Hindelang Prize as the most significant contribution to criminology in a three-year period. See generally KLECK, supra note 36 (discussing gun control and violence in America). The award is given by the American Society of Criminology, the major organization of academic criminologists. John Lott has been awarded research chairs at the University of Chicago and Yale Law School. The authors of another major study casting doubt on gun control, see JAMES D. WRIGHT ET AL., UNDER THE GUN: WEAPONS, CRIME, AND VIOLENCE IN AMERICA (1983), include a former President of the American Sociological Association and another winner of the Hindelang Prize. 
cerned about what might result if an administrative agency were given administrative authority to impose "safe" gun designs.

The HELP Network, to which Teret and Vernick's research center belongs, states, "many believe that the gun industry-like other industries-should be required to make their products as safe as possible. ${ }^{73}$ Manufacturers, however, are required not to make their products "as safe as possible," but only to include safety features that do not impede the usefulness of the products. Automobiles could be much safer if they weighed six tons and had regulators on their engines to ensure a maximum speed of fifteen miles per hour. For every consumer product, there are trade-offs between safety and functionality. The trade-offs proposed in the name of "treating guns like consumer products" are doubly dangerous. First, they will fail at their primary goal of reducing gun accidents and will instead increase accidents. Second, these trade-offs will reduce the usefulness of guns to fulfill their primary purpose of saving lives in lawful self-defense.

When the issue is stated at a high level of abstraction, however, the Teret and Vernick proposals seem appealing. Teret and Vernick's research center reports:

There is overwhelming public support for the regulation of guns as consumer products, especially with regard to safety. Seventy-five percent (75\%) of those surveyed support government safety regulations for gun design. Eighty-six percent (86\%) support legislation requiring all new handguns to be childproof and $68 \%$ favor legislation requiring all new handguns to be personalized (guns that, by design, can only be fired by an authorized user).

The high "yes" numbers on this survey reflect the fact that most people cannot think of any reason why guns should not be "childproof" and cannot imagine that "childproof" gun laws might actually increase gun accidents. Or respondents may have wanted to supply the "politically correct" answer.

${ }^{73}$ Legislation and Litigation Target Guns as Consumer Products, HELP NETWORK NEWS, Winter/Spring 1998, at 1.

74 NAT'L OPINION RESEARCH CTR., supra note 38, at 1.

${ }^{73}$ For some of the literature on polling respondents' tendency to say what they think the pollster wants to hear, see, e.g., HADLEY CANTRI, GAUGING PUBLIC OPINION 118 (1944) (noting that the opinions collected by interviewers tend to correlate with the opinions of the interviewers themselves); H.H. HMMAN ET AL., INTERVIEWING IN SOCIAL RESEARCH 34 (1954) (examining the relationship between interviewers and respondents and the bias effects that can occur); SEYMOUR SUDMAN \& NORMAN $M$. BRADBURN, RESPONSE EFFECTS IN SURVEYS: A REVIEW AND SYNTHESIS 10 (1974) (observing the pressure in an interview situation to agree with the interviewer "insofar as one can determine her opinion"); Robert M. Groves \& Lou J. Magilavy, Estimates of In- 
In this Part, I begin by examining some of the particular mechanical devices which Teret and Vernick favor. Next, I address Teret and Vernick's proposal for a "smart gun," and show the serious dangers caused by this nonexistent product. The next section examines the endgame of treating guns like consumer products: allowing handguns to be banned by administrative fiat. Finally, I address the issue of self-defense and how advocates of treating guns like consumer products ignore the harm that their proposals will cause by reducing citizens' ability to engage in lawful self-defense. The harm is ignored because the advocates morally oppose the use of guns for lawful selfdefense.

\section{A. Magazine Disconnects}

A minority of firearms manufacturers puts a "magazine disconnect" in their self-loading pistols. The magazine disconnect prevents a shooter from firing when there is a round in the chamber but the magazine is not in the gun. Some gun owners prefer guns with magazine disconnects, but others fear that the magazine disconnect might prevent the gun from firing in an emergency. For example, if a person under attack needed to reload a semiautomatic pistol and dropped the fresh magazine that she was trying to insert into the gun, the gun would not work. Even with a round left in the chamber, the victim would not be able to use that round to stop the attacker. The magazine disconnect could thus result in the murder of an innocent victim.

One of Teret and Vernick's monographs features a speech by a lawyer for an anti-gun organization who sued Beretta over the company's decision not to put a magazine disconnect on its self-loading handguns. In California, the parents of a teenager who was shot and killed by a friend during careless gun play sued the gun's manufacturer. The Center to Prevent Handgun Violence represented the vic-

terviewer Variance in Telephone Surveys, in AMERICAN STATISTICAI ASs'N, 1980 PROCEEDINGS OF THE SECTION ON SURVEY RESEARCH METHODS, 622, 622-27 (1980) (presenting a study of telephone interviewers and attempting to estimate variance in poll results due to interviewers and finding in this case that the effect is real but less than that of personal interviews); David Riesman, Orbits of Tolerance, Interviewers and Elites, 20 PUB. OPINION Q. 49, 64 (1956) (asserting that interviewers must demonstrate knowledge on politically charged topics to avoid respondents using "politeness as a screen against disclosure or self-exploration"); Seymour Sudman et al., Modest Expectations: The Effects of Interviewers' Prior Expectations on Responses, 6 SOC. METHODS \& RES. 171 (1977) (stating that one "possible source of response effects in survey measurement is the interviewer's expectations about respondents' answers"). 
tim's parents. ${ }^{76}$ Although the lawsuit was brought in San Francisco, hardly a "pro-gun" jurisdiction, the jury rejected the claim that the gun manufacturer should be responsible for the consequences of gun misuse. $^{77}$

If guns were possessed legitimately only for sporting purposes, then magazine disconnects should be required equipment. If a sporting shooter cannot fire a round because a magazine has been dropped, the worst scenario is that the shooter loses a target shooting match or that a hunted animal escapes. If firearms are legitimately possessed for protection, however, many gun buyers will choose not to buy guns that might fail to function in an emergency. Thus, many firearms companies will make firearms which defensive buyers wantguns without magazine disconnects.

\section{B. "Childproof" Devices such as Locks}

The notion of forcing firearms to contain equipment that could theoretically prevent them from being fired by small children is also high on the agenda of "treating guns like consumer products." A government mandate on this equipment is likely to increase, rather than decrease, accidental deaths.

According to Teret and Vernick's survey, the potential consumer market for guns with "childproof" equipment is huge. The Teret and Vernick survey asked: "Even though you said you were unlikely to buy a gun in the future, do you think you would ever consider buying a childproof handgun?" Just over thirty-five percent said "yes."78 The prospect of opening up a huge additional market-one-third of all homes that do not have guns-would be attractive to any rational consumer products company. There is, therefore, no need for the government to force firearms companies to pursue profit opportunities that the companies are neglecting.

Any company that markets a "childproof" gun-and any public policy expert who urges mandates for such guns-must recognize that

${ }^{76}$ See Mark D. Polston, The State of Gun Litigation, in Association OF TRIAL LAWYERS OF AM. \& JOHNS HOPKINS GTR. FOR GUN POL'Y \& RES., MAKING CHANGES IN MAKING GUNS 22, 23 (1995) (discussing design defects, particularly of Beretta semiautomatic handguns, and their involvement in litigation in which CPHV is representing the parents of a boy killed in an unintentional shooting).

${ }^{77}$ For information on this unreported case of Dix v. Beretta U.S.A. Corp., Alameda Cty. Sup. Ct., No. 7506819, see Henry K Lee, Gunmaker Not To Blame for Berkeley Boy's Slaying, Jury Decides, S.F. CHRON., Nov. 17, 1998, at A17.

78 NAT'L OPINION RESEARCH CTR., supra note 38, at 29. 
such guns will be left around children more often. After all, if the gun is really "childproof," there is no risk in leaving it near children. No one, however, would seriously propose treating a gun so casually because no one would risk a child's life or a commercial claim that a product is totally childproof. Moreover, despite the rhetoric about "childproof" guns, it is doubtful that a truly childproof device can ever be made. At best, a "childproof" device of any type could only reliably be expected to deter children under age six or thereabouts who would have neither the strength nor the ingenuity to defeat a safety device. ${ }^{79}$ Design-standard modifications would be of little benefit in reducing the more common type of childhood gun accident, involving preteen and older boys. ${ }^{80}$ According to the National Center for Health Statistics, in 1997 there were twenty fatal gun accidents involving children aged zero to four, and 122 such accidents for children aged five to fourteen. ${ }^{81}$ Today's allegedly "childproof" gun products are still not truly childproof. ${ }^{82}$ If a gun with a trigger lock is dropped accidentally, the gun could discharge. Every gun sold in the United States today is built not to fire if dropped, but a trigger lock, despite its billing as a safety feature, may defeat this important safety innovation. ${ }^{83}$

In short, safety devices may reduce the possibility of a gun being fired carelessly, but they cannot eliminate that possibility. That is why the National Rifle Association, and every other organization that conducts firearms safety training, teaches three rules of gun safety. First, "always keep the gun pointed in a safe direction;" second, "keep your

${ }^{79}$ See generally GENERAL ACCOUNTING OFFCE, ACCIDENTAL SHOOTINGS: MANY DEATHS AND INJURIES CAUSED BY FIREARMS COULD BE PREVENTED (1991).

${ }^{80}$ See Comm. on Adolescence, Am. Academy of Pediatrics, Policy Statement: Firearms and Adolescents, AAP NEWS, Jan. 1992, at 20 ("Modifications in gun design are unlikely to reduce injury, since those at greatest risk are preteen and teenage boys, both of whom possess adult abilities to circumvent gun safety features.").

${ }^{81}$ See CENTERS FOR DISEASE CONTROL \& PREVENTION, U.S. DEP'T OF HEALTH AND HuMAN SERVS., NATIONAI VITAL STATISTICS REPORT: DEATHS: FINAI DATA FOR 1997, Vol. 47, No. 19, tbl.16 (1999).

${ }^{82}$ See John Ellement, Despite Gun-ban Debate, Some Families at Home on the Shooting Range, BOSTON GLOBE, July 6, 1998 (reporting that " $[t]$ hose experienced with handguns know, for example, that a gun can still be manipulated or tampered with to discharge even if a trigger lock is engaged").

${ }^{83}$ In previous decades, there were guns that would fail the "drop test." Productliability suits against the makers of these guns made it uneconomical to produce such guns. Thus, guns have always been subject to product-liability suits based on theories just like other product-liability suits involving consumer products. In contrast, the new lawsuits that have been filed by mayors are based on Teret/Nernick theories of gun design and are little more than vexatious attempts to enact gun control laws by bankrupting a thinly capitalized business. 
finger off the trigger until ready to shoot;" and third, "always keep the gun unloaded until ready to use. ${ }^{84}$ People who follow these rules will never cause a gun accident. If people believe that some mechanical device has rendered a gun harmless, they may be more careless about following the safety rules. Accidents will be the inevitable result.

"An analogy might be drawn to preventing aspirin-related poisoning deaths to children," writes Teret. ${ }^{85}$ Teret provides a good analogy, but it works against his intended point. Federal laws requiring "childproof" safety caps for analgesics such as Tylenol have apparently led to an increase in child poisonings. Lulled by the presence of the federally-required safety device on medicine bottles, many adults have been leaving dangerous medicines within easy reach of children. These "childproof" caps are merely child-resistant. ${ }^{86}$ A child could get into a bottle left within his reach if the cap was put on improperly. Alternatively, a child can simply break open the bottle or cut through it with a knife.

Mandatory seat belt laws have a similar "lulling" effect: they paradoxically increase the deaths of innocents. Seat belts make it much more likely that automobile occupants will survive a crash, so for decades, safety-conscious drivers and passengers have worn safety belts voluntarily. In recent years, however, governments have begun imposing fines on automobile occupants who choose not to buckle up. Although this strategy may increase seat belt use, it also increases the deaths of innocent people. Studies have shown that when forced to buckle up, reluctant bucklers drive faster; recognizing that they are safer with the seat belts on, these drivers compensate for the increased safety by driving more aggressively. ${ }^{87}$ As a result, innocent pedestrians

${ }^{84}$ National Rifle Association, NRA Gun Safely Rules (visited Mar. 8, 2000) <http://www.nrahq.org/safety/education/guides.html>.

${ }^{85}$ Stephen P. Teret, How Can Guns Be Changed?, in Association OF TrIal LawYers OF AM. \& JOHNS HOPKINS CTR. FOR GUN POL'Y \& RES., MAKING CHANGES IN MAKING GUNS 19, 20 (1995).

${ }^{36}$ See W. KIP VISCUSI, FATAL TRADEOFFS: PUBLIC AND PRIVATE ResPonsibILImes FOR RISK $234-42$ (1992) (examining the upward shift in analgesic poisoning rates in children after the imposition of the safety-cap regulation). But see The Safety Effects of Child-Resistant Packaging for Oral Prescription Drugs: Two Decades of Experience, 275 JAMA 1661, 1661 (1996) (finding a significant reduction in child mortality from unintended ingestion of drugs when child resistant packaging is used).

${ }_{87}$ See GLENN C. BLOMQUIST, THE REgULATION OF MOTOR VEHICLE AND TRAFFIC SAFETY 68 (1988) (concluding that car safety regulations lead drivers to engage in increasingly risky behavior behind the wheel); Sam Peltzman, The Effects of Automobile Safety Regulation, 83J. POL. ECON. 677, 717 (1975) (arguing that lowering the potential harms of unsafe driving increases the risk of automobile accidents). 
and occupants of other automobiles are injured or killed in accidents caused by the extra risk-taking that resulted from mandatory seat belt laws. In essence, the government increases the safety of careless people at the expense of the safety of careful people. Even if this policy results in a net saving of lives, it is immoral to kill (indirectly) innocents in order to protect fools from their folly.

With firearms, the consequences of the lulling effect will be much deadlier than with medicine caps or seat belts. If the government claims that a gun is "childproof"-because it has some device that the government mandated-then firearms safety training will be severely undermined. If the gun is "childproof," then many parents will be less cautious with regard to firearm-safety rules and allow their children to be careless. For example, parents and children alike might point the gun in a dangerous direction, put a finger on the trigger even when not ready to shoot, or store the gun loaded, even when the gun is used only for sporting purposes. These behaviors might not cause harm as long as the "childproof" devices work properly. What happens, though, when these adults and children-conditioned to ignore gun safety rules-come across a gun that does not have one of these devices? Whatever laws may be enacted today, a supply of eighty million handguns currently exists in American homes, hardly any of which have the Teret/Vernick devices. Moreover, the Teret/Vernick proposals would not apply to any newly produced or any of the extant supply of 160 million rifles and shotguns. It is terrifying to imagine what will happen when people who think that guns are "childproof"because the government told them so-encounter guns that are not "childproof.",

8s In addition to increased accidents, another consequence of a government mandate for "childproofing" would be an increased number of crime victims killed because they could not defend themselves in time. A 1998 event in which "guns as consumer products" lawyer Dennis Hennigan of the Center to Prevent Handgun Violence was attempting to convince mayors to sue gun companies for allegedly not producing "childproof" guns illustrates the problem:

Dennis Hennigan [sic] . . . drops the ball in front of a roomful of reporters, while trying to prove the efficacy of Saf T Lok, a purportedly easy-to-use combination lock in the gun's grip. Hennigan [sic] fumbles and fails to unlock the gun in a well-lit room with no intruder at the door. . . . Finally, disengaging the safety, he apologizes, "Most people aren't as klutzy as I am."

Matt Labash, Lawyers, Guns, and Money, WKIY. STANDARD, Feb. 1, 1999, at 25, 29.

The Saf-T-Lok company claims that the lock can be disengaged in less than three seconds; Teret and Vernick tout the manufacturer's claim to show that the handgun can still be used for self-defense. See KRISTA D. ROBINSON ET AL, THE JOHNS HOPKINS CTR. FOR Gun POLICY \& Research, Personalized Guns: Reducing Gun DEATHS THROUGH DESIGN CHANGES 5, 6 (2d ed. 1998) (noting that Saf-T-Lok "effectively per- 
It is fair to say that consumers are not rushing to buy the paraphernalia that Teret, Vernick, and their allies would mandate. If Teret and Vernick really believe that there are genuinely childproof (not merely child-resistant) devices that will not impede a firearm's utility for defense of innocent life, then they should promptly set up a "Safety Handgun Company" and sell firearms to a brand new market segment. The consistent failure of these products in the free market is a much better guide to what consumers really want than the snap answer that people give to pollsters after the pollsters have warmed them up with comments about child safety. ${ }^{89}$

sonalize[s] the weapon"). But the median gunfight lasts 2.7 seconds. See Bill Clede, Thinking of Making the Big Swilch?, POIICE MARKSMAN, Feb. 1987, at 26, 27. In other words, even by Saf-T-Lok's estimation, the typical gunfight will be over before the SafT-Lok can be disengaged. The victim will be dead; only the criminal will be safer.

${ }^{89}$ Yet while gun consumers do not want, and therefore, gun companies do not produce, firearms with the equipment that the "consumer products" advocates favor, there have been substantial changes in firearms production in recent years. These changes make guns much safer, but arouse the ire of the "consumer products" advocates.

Most self-loading handguns have a safety lever or switch to prevent the gun from accidentally firing. The trigger mechanism can operate only if the safety is turned off. In addition, to load a round into a self-loading pistol, one must pull back on the top part of the gun (the slide) to chamber the round. Pulling the slide requires substantial physical force, more than many young children can muster. Many children will be unaware of how to engage the slide at all, and thus unable to load the gun. By contrast, revolvers have no safety mechanism. One needs only pull the trigger in order to shoot a revolver. One of the most important changes in the U.S. firearms market in the last three decades is that handgun consumers have begun purchasing mostly self-loading pistols, rather than revolvers. This fact is bemoaned by one of Teret and Vernick's "consumer products" advocates, Dr. Garen Wintemute, see Garen J. Wintemute, Overview of the Gun Industry, in ASSOCIATION OF TRIAL LAWYERS OF AM. \& JOHNS HOPKINS CTR. FOR GUN POL'Y \& RES., MAKING GHANGES IN MAKING GUNS 11, 13-14 (1995), and held up as proof of the gun industry's wickedness by the Violence Policy Center, see TOM DIAZ, MAKING A KIIIING 96-105 (1999) (discussing the turn of the U.S. market from revolvers to pistols).

Another important pro-safety change is just beginning. Ten years ago, only scientists had lasers on firearms. Today, lasers are after-market accessories that range in cost from several hundred to less than one hundred dollars. Firearms companies are now beginning to integrate lasers into the original equipment of the firearm. Wintemute, in a volume edited by Teret and Vernick, complains that the user "does not have to aim carefully, but simply point to put the bullet where the red dot is." Wintemute, supra, at 14. This reduces risk of stray shots and increases the probability of successful self defense, even by nonexpert shooters.

Again, if guns are only used for sporting purposes, then perhaps it is logical to make it as challenging as possible to fire guns accurately and to mandate devices that may make the gun fail to function properly. If guns are also for home defense, however, the existing consumer-products market is already making guns less prone to accidental misuse and better suited for defensive use. 


\section{Unreliable Guns Are Not "Smart"}

The "childproof" gun issue is a minor league version of a major gun control issue which Teret and Vernick have created almost singlehandedly: "smart" guns. As with "childproof" guns, consumers say that they want a "smart" gun. When asked, thirty-five percent of nongun owners responded affirmatively to the following question: "Even though you said you were unlikely to buy a gun in the future, do you think you would ever consider buying a handgun that would only fire for the owner of the gun?" Consequently, the first gun company to create such a product will likely reap a considerable profit. Given this financial incentive, there is no need for the "technology-forcing" mandate advocated by Teret and Vernick. ${ }^{11}$

As with so-called "childproof guns," "smart guns" might reduce some of the twenty annual fatal gun accidents involving small children. As the Violence Policy Center's Josh Sugarmann points out, however:

The flaw in "smart" guns, with devices that allow only so-called "authorized users" to fire them, is that the vast majority of death and injury is caused by the people the guns would be programmed to recognize as authorized: from people who commit suicide to angry spouses to criminals who will simply get their smart guns from organized traffickers.

Even the accident-reduction gains of "smart guns" are likely to be more than offset by increased fatalities from the same kinds of problems that would plague "childproof" guns. First, adults and children will be less likely to obey gun safety rules because they will believe that the "smart" technology will make an accident impossible, and therefore more likely to cause an accident with the "smart gun" itself or any of the 240 million older guns they encounter. Second, the high costs of "smart guns" may make gun ownership impossible for some people. The kind of people who live in a poor neighborhood with little police protection and rely on a $\$ 75$ pistol for protection may not be able to

90 NAT'L OPINION RESEARCH GTR., supra note 38, at 30.

${ }^{91}$ One company has already made a lot of money from smart guns. Despite the fact that Colt has been in and out of bankruptcy and near financial ruin for over a decade, the company's smart gun project has brought millions of dollars of corporate welfare ("research grants") from the federal government. Back in 1996, Teret enthusiastically reported that "[Colt] plans to offer the gun for use by police officers within the next few years." Krista D. Robinson eT AL., PERSONALIZEd HANDGUNS: REDUCing GUN DEATHS THROUGH DESIGN CHANGES 8 (1996). More than three years later, Colt is nowhere near bringing any such gun to market.

${ }^{92}$ Josh Sugarmann, Laws That Can't Stop a Bulleh N.Y. TimES, Nov. 4, 1999, at A29. 
defend themselves if the cost rises to $\$ 150$ or more because of a Teret/Vernick-inspired mandate. Since many of these poor people will not have small children in the home, there is no realistic safety benefit gained from the government forcing them to buy guns with expensive technology. Mandating this unneeded technology would be de facto prevention of the poor from buying guns. ${ }^{93}$

No group would benefit more from a truly reliable, personalized gun than police officers; nine percent of all murders of the police are perpetrated with a gun that has been snatched from a police officer. ${ }^{94}$ As opposed to defensive handguns carried by ordinary citizens, which by law must usually be concealed, ${ }^{95}$ police guns are uniquely vulnerable to being stolen because they are normally worn on an exposed belt holster.

When Sandia Labs in New Mexico evaluated every known form of personalized gun technology for possible police adoption, reliability problems prevented any technology from receiving better than a " $\mathrm{B}$ " grade. ${ }^{96}$ Although personalized gun advocates may claim that various technologies are completely reliable, Teret and Vernick's model bill to mandate personalized guns illustrates the unreliability of those technologies. The bill exempts police guns. ${ }^{97}$ This exemption seems rather strange since the police have much to gain from personalized guns that work correctly. As Teret and Vernick appear to recognize, however, police opposition would instantly kill any smart gun bill, and

${ }^{93}$ In addition, "smart guns" have reliability problems similar to "childproof" guns. When Colt's Steve Sliwa pulled the trigger to demonstrate one of his company's prototypes, in which the gun is activated by a radio signal from a wristband, nothing happened. "For a while it worked fine," he remarked. Paul M. Barrett \& Vanessa O'Connell, Personal Weapon: How a Gun Company Tries to Propel Itself into the Computer Age, WALl St. J., May 12, 1999, at A1.

${ }^{\text {is }}$ See FBI, Law Enforcement Officers Killed and Assaulted (1997) <http://www.fbi.gov/ ver/killed/97killed.pdfs at 4 (visited March 21, 2000) (noting that 62 of the 688 officers killed in the line of duty from 1988 through 1997 were slain by their own guns).

${ }^{95}$ See BUREAU OF ALCOHOL, TOBACCO, AND FIREARMS, DEP'T OF THE TREASURY, STATE LAWS \& PUBLISHED ORDINANCES-FIREARMS (21st ed. 1998) (providing a list of state laws and ordinances regarding firearms and their use).

${ }^{96}$ See D.R. WEISS, NatIONAL INST. OF JuSTICE, SMART GUN TECHNOLOGY PROJECT FINAL REPORT 6-9 (1996) (evaluating several technologies and noting that "the highest grade that any of the technologies received was a ' $\mathrm{B}$ '").

97 See SUSAN DEFRANCESCO ET AL., THE JOHNS HOPKINS CTR. FOR GUN POLICY AND RESEARCH, A MODEL HANDGUN SAFETY STANDARD ACT $\$ 7$ (2d ed. 1998) (exempting certain handguns from the Model Act); see also Responsible Gun Safety Act of 2000, H.R. 279, 414th Sess. (Md. 2000) (exempting both state and local law enforcement from regulations requiring the use of personalized firearms upon a commission recommendation). 
police opposition would be gigantic, were the police included in the bill.

Simply put, the police will not tolerate a gun that is any less than completely reliable. Furthermore, since civilians, like law enforcement officers, have the legal right to use deadly force to protect themselves or others from serious violent felonies when lesser force would be insufficient, ${ }^{98}$ civilians are just as entitled as police officers to be able to purchase completely reliable firearms.

Teret and Vernick justify the exemption for police officers by claiming that "[a]lthough law enforcement officials are often killed or injured with their own firearms and would benefit from personalized guns, they may require guns with slightly different technology than guns for domestic use. ${ }^{99}$ Teret and Vernick's argument is unsound. The firearms needs of an ordinary citizen being attacked by three gangsters are nearly identical to those of a police officer being attacked by three gangsters. If police and domestic needs are different at all, the differences militate in favor of granting domestic users, not the police, the exemption. An ordinary citizen may experience more stress during a confrontation and thus be more likely to have sweaty hands or to shake while holding the gun, thereby preventing a palmprint reader (one form of personalization technology) from working. Citizens away from home are also much less likely to carry a second back-up gun than police officers, who commonly carry back-up guns in ankle holsters. Thus, the civilian is less likely to have an alternative if the first gun fails to operate. Furthermore, while police officers handle their guns every day, most domestic users who keep a gun for home protection do not; thus, the police officer will be alerted when a battery needed to operate a personalized gun has gone dead and needs to be replaced. The homeowner may not discover the dead battery until he picks up the gun during an emergency.

If personalized handguns really are reliable, then another change is needed to their model act. Besides taking out the police exemption, Teret and Vernick should insert a provision waiving sovereign immunity and providing full compensation for lawful gun owners (or

${ }^{93}$ Every state in the Union authorizes civilian use of deadly force, as does the Model Penal Code. See, e.g., LA. REv. STAT. ANN. $\$ 14.20$ (West 1997 \& Supp. 2000) (denoting a homicide as justifiable if committed in self-defense); N.Y. PENAL LAW $\$$ 35.15 (McKinney 1999) (permitting the use of deadly force if it is reasonably believed that an attacker is using or will use deadly force); MODEL PENAL CODE $§ 3.04$ (2) (b) (1962) (allowing the use of deadly force if "necessary to protect against death, serious bodily harm, kidnapping, or sexual intercourse compelled by force or threat ${ }^{n}$ ).

${ }^{99}$ DEFRANCESCO ET AL., supra note $97, \S 7$. 
their estates) who are injured or killed because an allegedly "smart" gun failed to function. If smart guns are reliable, then there should be no objection to assuaging the fears of skeptics; and this reassurance will cost the government nothing. On the other hand, if smart guns are not really smart enough to put the state treasury at risk, neither should the safety of crime victims be put at risk.

\section{Banning Guns}

The endgame of "treating guns like consumer products" is letting an administrative agency impose handgun prohibition. Josh Sugarmann demands that Congress

pass far-reaching industry regulation like the Firearms Safety and Consumer Protection Act introduced by Senator Robert Torricelli, Democrat of New Jersey, and Representative Patrick Kennedy, Democrat of Rhode Island. Their measure would give the Treasury Department health and safety authority over the gun industry, and any rational regulator with that authority would ban handguns. ${ }^{100}$

As detailed in a book by Tom Diaz, Sugarmann's colleague at the Violence Policy Center, this administrative authority should also be used to prohibit various types of rifles and shotguns. ${ }^{101}$ Put aside the constitutional arguments against these proposals. ${ }^{102}$ Put aside the benefits in the cost/benefit calculus and assume that wiping out defensive handgun use is of no consequence. ${ }^{103}$ Even so, the costs of handgun prohibition are certain to be enormous-for the same rea-

${ }^{100}$ Sugarmann, supra note 92 , at A29.

${ }^{101}$ See DiAZ, supra note 89, at 205-06.

${ }^{102}$ The constitutional arguments are that the Second Amendment allows gun regulation but not gun prohibition, and that the Commerce Clause should not be interpreted to give the federal government the power to ban the simple possession of any object. For the latter argument, see generally David B. Kopel \& Glenn Reynolds, Taking Federalism Seriously: Lopez and the Partial-Birth Abortion Ban Act, 30 CONN. L. REv. 59 (1997), which argues that the Commerce Clause should be construed only to authorize regulation of interstate commerce, not prohibition of acts or items within a single state. For the former argument, see, for example, Glenn Harlan Reynolds, $A$ Crilical Guide to the Second Amendment, 62 TENN. L. REV. 461 (1999), which notes that the "Standard Mode" of Second Amendment scholarship allows reasonable regulation of firearms, but not prohibition.

${ }^{103}$ For estimates on annual defensive gun use, see Kleck \& Gertz, supra note 63 , at 182-87 (providing statistics on defensive gun use, both from previous studies and from more current research). For Kleck's response to critiques of his research, see Gary Kleck, Degrading Scientific Slandards to Get the Defensive Gun Use Estimate Doum, $11 \mathrm{~J}$. FIREARMS \& PUB. POL'Y 77 (1999). 
son that alcohol and drug prohibition imposed enormous costs. ${ }^{104}$ There are tens of millions of people who will be turned into criminals by a prohibition law and who will become customers for an immense black market. Today's American prisons contain more drug criminals than violent criminals; the number of "criminals" who violate handgun prohibition laws may well exceed the number of people who currently violate the drug prohibition laws. The devastation that drug prohibition has imposed on the Constitution is immense-including, but not limited to, a massive weakening of Fourth Amendment protections from illegal searches and Fifth Amendment protections against the taking of property without due process. ${ }^{105}$ The drug "war" has also been the main engine for the militarization of American law enforcement, which has led to increased violence and death, and erosion of civilian control over the military. ${ }^{106}$ Arguably, all of these costs were worthwhile for alcohol prohibition, and are worthwhile for drug prohibition since both alcohol and drug abuse have many destructive consequences. If the United States is to launch itself into another prohibition war that will be at least as costly as drug prohibition and that could set off a literal civil war, then such a momentous decision should be made by an elected legislature and not by a three-man majority of some five-member commission.

Public opinion polls show that a very large majority of the American public opposes handgun prohibition. ${ }^{107}$ Every time handgun pro-

${ }^{104}$ See David B. Kopel, Peril or Protection? The Risks and Benefits of Handgun Prolibition, 12 ST. LOUIS U. PUB. L. REV. 285, 319 (1993) (alleging that the war on drugs has become a "War on the Constitution"). These costs can be mitigated, but not avoided, by phasing in prohibition gradually. Alcohol and drug prohibition were both phased in gradually but still imposed enormous costs. Alcohol prohibition started out in only a few states. Drug prohibition started out merely as taxation of opiates, then turned to prohibition of opiates, and later encompassed marijuana, and still later encompassed other drugs. See RICHARD J. BONNIE \& CHARLES H. WhITEBREAD II, THE MARJJUANA CONVICTION: A HISTORY OF MARIJUANA PROHBITION IN THE UNITED STATES (1999) (detailing the development of marijuana use and legislation in the United States); STEVEN B. DUKE \& AIBERT C. GROSS, AMERICA'S LONGEST WAR: RETHINKING OUR TRAGIC CRUSADE AGAINST DRUGS 6-11 (1993) (arguing that we should rethink our crusade against drugs because it has become too costly).

${ }^{105}$ See, e.g., HENRY HYDE, FORFEITING OUR PROPERTY RIGHTS: IS YOUR PROPERTY SAFE FROM SEIZURE? (1995) (proposing forfeiture reform); The Incredible Shrinking Fourth Amendment, 21 AM. CRM. L. REV. 257, 261 (1984) (describing the "dismembering" of Fourth Amendment law by the Burger Court).

${ }^{106}$ See generally David B. Kopel, Militarized Law Enforcement: The Drug War's Deadly Fruil, in BEYOND PROHIBITION: AN ADULT APPROACH TO DRUG POLICIES IN THE 21ST CENTURY (forthcoming 2000).

${ }^{107}$ See NBC News Poll, Jan. 24, 1994 (noting that the majority of Americans oppose the prohibition of handguns); see also Morton Kondracke, Gun Conlrol Issue Could Hurt 
hibition has appeared on the ballot anywhere in the United States it has lost, usually by a landslide. ${ }^{108}$ Unsurprisingly, there is not a single state where a handgun prohibition bill has passed even a single legislative body in the last three decades. Is all this to be swept away by three men on some commission in a building in Washington, D.C.? Handgun prohibition advocates have every right to continue to argue their case to the public; but until they convince the public, a decent respect for our republican form of government requires that prohibition not be imposed by administrative fiat.

\section{CONCLUSION}

Guns should be treated like a particular set of consumer products: consumer products that are protected by the Constitution. ${ }^{109}$ These

GOP, COMMERICAL APPEAL, Oct. 8, 1999, at A9 (noting that according to a CBS poll, "by 61 to 35 percent, the public opposes a nationwide ban on handgun sales"); Lelters, TIME, Aug. 30, 1999, at 14 (noting that a Gallup poll showed that only $62 \%$ of Americans favor stricter gun laws and only $38 \%$ believe the government should ban handgun possession); Voters Vs. Lobbyists; Proposal Would Put Assault Weapons to a Vote, SUN SENITNEL, Nov. 21, 1999, at $6 \mathrm{H}$ (noting that only one in three Americans wants a fullscale ban on handguns, according to a Washington Post/ABC poll).

${ }^{103}$ For example, such prohibitions were defeated in Massachusetts (1976) (69.2\%); California (1982) (63\%); Madison, Wisconsin (1993) (51\%); Milwaukee, Wisconsin (1994) (67\%); Kenosha, Wisconsin (1994) (73\%). See, e.g., NATIONAL RIFLE Association, THE WAR AgAINST HANDGUNS 10 (1999) ("Fact Sheet" from NRA's Institute for Legislative Action, reporting results of Nov. 8 and 19 votes in Madison, Milwaukee, and Kenosha); Handgun Ban Loses in Milwaukee Vote, GH. TRIB., Nov. 9, 1994, at 24 (reporting the rejection of Milwaukee's total handgun ban by $67 \%$ ). For more on the votes, see Brendan F.J. Furnish, The New Class and the Califormia Handgun Initiative: Elitist Developed Law as Gun Control, in THE GUN Gulture AND ITS ENEMIES 147 (William R. Tonso ed., 1990), which discusses the California vote, and David J. Bordau, Adversary Polling and the Construction of Social Meaning: Implications in Cun Control Elections in Massachuisetts and California, 5 L. \& POL'Y Q. 345 (1983), which discusses the gun control lobby and polling tactics and reports Massachusetts results.

${ }^{109}$ The Supreme Court, in over two dozen cases, including several from the past decade, has recognized the Second Amendment as an individual right. See, e.g., Muscarello v. United States, 524 U.S. 125, 143 (1998) (Ginsburg, J., dissenting) (stating that "carrying" a firearm should be interpreted by reference to the familiar meaning of "to bear arms" for personal use found in the Second Amendment); Printz v. United States, 521 U.S. 898 (1997) (Thomas, J., concurring) (reading the Second Amendment to guarantee a "personal right"); Planned Parenthood v. Casey, 505 U.S. 833, 847-48 (1992) (citing the Second Amendment in a discussion of the scope of the personal liberty guaranteed by the Fourteenth Amendment); United States v. Verdugo-Urquidez, 494 U.S. 259, 265 (1990) (stating that "the people" protected by the Second Amendment are the same as "the people" protected by the First, Fourth, and Ninth Amendments);Moore v. City of East Cleveland, 431 U.S. 494, 502 (1977) (citing the Second Amendment in a discussion of the scope of the personal liberty guaranteed by the Fourteenth Amendment); Roe v. Wade, 410 U.S. 113, 169 (1973) (Stewart, J., concurring) (same) 
include books, Bibles, and birth control devices. For all of these products, a certain degree of government regulation is accepted. A store that wishes to sell Bibles must comply with zoning laws and pay sales taxes. As detailed in Part I, firearms are already subject to a host of regulations-more so than perhaps any other consumer product.

Duncan v. Louisiana, 391 U.S. 145, 167 (1968) (same); Poe v. Ullman, 367 U.S. 497, $542-43$ (1961) (Harlan, J., dissenting) (same); Johnson v. Eisentrager, 339 U.S. 763, 784 (1950) (discussing the Second Amendment as similar to petitioners' Fifth Amendment rights when filing a writ of habeas corpus); United States v. Miller, 307 U.S. 174, 178 (1939) (discussing the application of the Second Amendment to a sawedoff shotgun); Kepner v. United States, 195 U.S. 100, 123-24 (1904) (noting that the right to bear arms did not apply to people in the Philippines); Robertson v. Baldwin, 165 U.S. 275, 281-82 (1897) (noting that a person's right to keep and bear arms is not infringed by laws prohibiting him to carry a concealed weapon); Brown v. Walker, 161 U.S. 591, 635 (1896) (Field, J., dissenting) (noting that the right to bear arms is an "essential and inseparable[] feature of English liberty"); Miller v. Texas, 153 U.S. 535, 538 (1894) (noting that the Second Amendment has "no reference to proceedings in state courts"); Presser v. Illinois, 116 U.S. 252, 265 (1886) (same); United States v. Cruikshank, 92 U.S. 542, 553 (1875) (declaring that the Second Amendment is not infringed by private conduct and that the right to arms predates the Constitution); Scott v. Sandford, 60 U.S. (19 How.) 393, 449-50 (1856) (superseded by constitutional amendment) (noting that Congress cannot "deny to the people the right to keep and bear arms"). In all cases for which dissents are listed, the dissent was on grounds other than the Second Amendment, and the majority opinion did not contradict the dissenters' analysis of the Second Amendment. See David B. Kopel, The Supreme Court's Thirty-Four Other Second Amendment Cases, 18 ST. LouIS U. PUB. L. REV. 99 (1999).

Even if we set the Second Amendment aside, there are 43 state constitutions that protect a right to bear arms. See ALA. CONST. art. 1, $\$ 26$ (protecting a right to bear arms); ALASKA CONST. art. I, $\S 19$ (same); ARIZ. CONST. art. II, $\$ 26$ (same); ARK. CONST. art. II, § 5 (same); COLO. CONST. art. II, § 13 (same); CONN. CONST. art. I, § 15 (same); FLA. CONST. art. I, \& 8 (same); GA. CONST. art. I, § 1, I VIII (same); HAW. CONST. art. I, § 17 (same); IDAHO CONST. art. I, § 11 (same); ILL. CONST. art. I, § 22 (same); IND. CONST. art. I, § 32 (same); KAN. CONST. bill of rights, $\S 4$ (same); KY. CONST. bill of rights, $\$ 1$, I 7 (same); LA. CONST. art. I, § 11 (same); ME. CoNST. art. I, \$ 16 (same); MASS. CONST. pt. 1, art. XVII (same); MICH. CONST. art. I, § 6 (same); MISs. CONST. art. III, $\S 12$ (same); MO. CONST. art. I, $\$ 23$ (same); MONT. CoNST. art. II, § 12 (same); NEB. CONST. art. I, § 1 (same); NEV. CONST. art. 1, § 11, cl. 1 (same); N.H. CoNST. pt. 1, art. 2-a (same); N.M. CONST. art. II, $\$ 6$ (same); N.C. CONST. art. I, $\S 30$ (same); N.D. CONST. art. I, § 1 (same); OHIO CONST. art. I, § 4 (same); OKIA. CONST. art. II, § 26 (same); OR. CONST. art. II, § 26 (same); PA. CONST. art. I, § 21 (same); R.I. CoNST. art. I, § 22 (same); S.C. CONST. art. I, § 20 (same); S.D. CoNST. art. VI, § 24 (same); TENN. CONST. art. I, § 26 (same); TEX. CONST. art. I, § 23 (same); UTAH CONST. art. I, § 6 (same); VT. CONST. ch. I, art. 16 (same);VA. CONST. art. I, § 13 (same); WASH. CONST. art. I, § 24 (same); W. VA. CONST. art. III, § 22 (same); WIS. CONST. art. I, § 25 (same); WYO. CONST. art. I, § 24 (same). In 42 of these states, the right has been construed as an individual right, Massachusetts being the lone exception.

Under state constitutions, 20 gun control laws have been declared unconstitutional over the years. For a list of cases, see David B. Kopel et al., A Tale of Three Cities: The Right to Bear Arms in State Supreme Courts, 68 TEMP. L. REV. 1177, 1180 n.12 (1995). 
The Grosjean case, however, teaches us that when the government singles out a constitutional consumer product for punitive taxation or regulation, the government oversteps its authority.

Guns should be treated like the constitutional consumer products they are. The current heavy regulation of firearms-more severe than that of nonconstitutional and highly dangerous products such as automobiles and alcohol-should be reformed. Firearms advertising that mentions self-defense should not be censored-for the same reason that other consumer product manufacturers are allowed to discuss controversial issues regarding their products. Firearms companies should be allowed to respond to consumer demand by making firearms ever safer in the home and more reliable in emergencies. Consumers, not professors or politicians, are the best judges of the types of firearms which consumers need to defend their families. Efforts to ban handguns or to impede armed self-defense are just as constitutionally impermissible as efforts to ban books or to impede free assembly. It will be a great day for the Second Amendment when American laws finally begin treating firearms like constitutional consumer products.

${ }^{110}$ Grosjean v. American Press Co., 297 U.S. 233, 250 (1936) (holding that a law imposing heavy tax on newspapers violated the First Amendment). 